\title{
sciendo
}

\section{Antisickling Effects of Quercetin may be Associated with Modulation of Deoxy- haemoglobin, 2, 3-bisphosphoglycerate mutase, Redox Homeostasis and Alteration of Functional Chemistry in Human Sickle Erythrocytes.}

\section{Aliyu Muhammad ${ }^{1 *}$, Aliyu Dahiru Waziri ${ }^{2}$, Gilead Ebiegberi Forcados ${ }^{1}$, Babangida Sanusi ${ }^{1}$, Hadiza Sani ${ }^{3}$, Ibrahim Malami ${ }^{4}$, Ibrahim Babangida Abubakar, Musa Fatima Abbah ${ }^{5}$, Ali Tony Nelson ${ }^{1}$, Bashir Musa and Hafsat Abdullahi Mohammed ${ }^{l}$}

\author{
${ }^{1}$ Department of Biochemistry, Faculty of Life Sciences, Ahmadu Bello University, Zaria, Kaduna State, Nigeria \\ ${ }^{2}$ Department of Haematology, Ahmadu Bello University Teaching Hospital, Zaria, Kaduna State, Nigeria \\ ${ }^{3}$ Department of Medicine, Kaduna State University, Kaduna State, Nigeria \\ ${ }^{4}$ Department of Pharmacognosy and Ethnopharmacy, Faculty of Pharmaceutical Sciences, Usmanu Danfodiyo University, PMB 2346, Sokoto, Nigeria \\ ${ }^{5}$ Department of Biochemistry, Faculty of Life Sciences, Kebbi State University of Science and Technology, Aliero, PMB 1144, Kebbi State, Nigeria
}

Received $8^{\text {th }}$ Feb. 2019, Accepted $7^{\text {th }}$ May, 2019

DOI: 10.2478/ast-2019-0005

*Corresponding author

Aliyu Muhammad E-mail: amachida31@gmail.com

Tel: $+234-7038161430$

\begin{abstract}
It is now glaring that sickle cell anaemia is still one of the highest leading inbred hemoglobinopathy amongst Africans. This study examined the antisickling effects of quercetin via modulation of deoxy-haemoglobin, redox homeostasis and alteration of functional chemistry in human sickle erythrocyte using in silico and in vitro models while espousing preventive and curative approaches. Quercetin was docked against deoxy-haemoglobin and 2, 3-bisphosphoglycerate mutase, with binding energies $(-30.427$ and $-21.106 \mathrm{kcal} / \mathrm{mol})$ and $\mathrm{Ki}$ of $0.988 \mu \mathrm{M}$ and $0.992 \mu \mathrm{M}$ at their catalytic sites via strong hydrophobic and hydrogen bond interactions. Induction of sickling was done using $2 \%$ metabisulphite at $3 \mathrm{~h}$. Treatment with quercetin prevented sickling outstandingly at $5.0 \mu \mathrm{g} / \mathrm{mL}$ and reversed same at $7.5 \mu \mathrm{g} / \mathrm{mL}, 83.6 \%$ and $75.9 \%$, respectively. Quercetin also significantly $(\mathrm{P}<0.05)$ maintained the integrity of erythrocyte membrane apparently from the observed \% haemolysis relative to untreated. Quercetin significantly $(\mathrm{P}<0.05)$ prevented and counteracted lipid peroxidation while stimulating GSH and CAT levels which were detected to considerably $(\mathrm{P}<0.05)$ increase with simultaneous significant $(\mathrm{P}<0.05)$ reduction in SOD level based on curative approach. Umpiring from our FTIR results, a favorable alteration in the part of functional chemistry in terms of shifts (bend and stretches) and functional groups were observed relative to the induced erythrocyte/untreated. Thus, antisickling effects of quercetin may be associated with modulation of deoxy-haemoglobin, redox homeostasis and alteration of functional chemistry in human sickle erythrocytes.
\end{abstract}

Keywords: Quercetin; antisickling; redox; erythrocytes; haemoglobin.

(cc) BY-NC-ND (C2019 Aliyu et al. This work is licensed under the Creative Commons Attribution-Non-Commercial-NoDerivs License 4.0 


\subsection{Introduction}

As one of the congenital disorder, sickle cell disease (SCD) is a health contest for many in Africa and some part of Asia (Macharia et al., 2018). It is appraised that approximately 20 to $30 \%$ of the Nigerian inhabitants harbuors sickle cell trait although about 2 to $3 \%$ of the population suffer from SCD (Adewoyin et al., 2015). The symptoms associated with the condition are attributed to a distinct nucleotide alteration in the beta globin gene, which predisposes hemoglobin with the altered amino acid sequence to increased polymerization, microscopically evidenced by red blood cells (RBC) taking a sickle shape (Adewoyin, 2015). This alteration to RBC shape alters not only the structure but also the function of this important protein, resulting in decreased blood flow and lower oxygen supply to tissues and organs (Rowley et al., 2014). Low oxygen levels further cause increased red cell deformation and polymerization which also cause damage to vascular endothelial cells (Sedrak and Kondamudi, 2018). Vascular endothelial cells dysfunction results in altered vascular tone, vascular adhesion and receptor function related with inflammatory responses and oxidative damage were observed in SCD patients (Teixeira et al., 2017). Oxidative stress during SCD has also been reported to cause depletion of cellular antioxidants resulting in increased lipid peroxidation and increased fragility of RBCs (Okorie et al., 2018).

Conveyance of oxygen from the lungs to tissues is a vital function carried out by RBCs. The ability of red cells to transport oxygen is reliant on the revocable binding of oxygen to $\mathrm{Fe}$ (II) hemoglobin (Mohanty et al., 2014). However, it is known that a slower rate of autoxidation generates superoxide radical, and the rate of autoxidation increases at stumpy partial pressures of oxygen (Rifkind et al., 2004). At lower oxygen pressures, increased hemoglobin binding to red cell membranes increases reactive oxygen species generation, leading to oxidative stress, prominently observed in the microvasculature (Mohanty et al., 2014). To neutralize this challenge, the molecule 2,3-bisphosphoglycerate, abundantly present in red cells, synthesized from 1,3-bisphosphoglycerate by bisphosphoglycerate mutase, binds to deoxy-hemoglobin, thereby stabilizing it and reducing oxygen affinity (Oslund et al., 2017; Poillon et al., 1995). This may invariably have negative effects in SCD patients, thereby aggravating the already existing precarious condition. Therefore, modulating deoxyhemoglobin and bisphosphoglycerate mutase levels could be yet another viable strategy in combating SCD.

At present, hydroxyurea is the permitted drug for use by sickle cell anaemia patients (Adewoyin et al., 2017). The drug functions by increasing fetal hemoglobin production, thereby sustaining the levels of normal red cell (Rees, 2011). Normal red cells are able to better supply oxygen to tissues and organs in these patients, thereby counteracting the anomalies caused by the sickle cells. However, HU is cytotoxic, and side effects from continuous use of the drug are a current concern (Brandow and Panepinto, 2010; Nevitt et al., 2017). Other therapies for SCD, including transfusion and gene therapy are relatively expensive, especially for low income earners who constitute the majority in developing countries. To this end, the utmost need for better and reliable alternatives with fewer side effects cannot be overemphasized.
One compound currently been examined for possible antisickling effects is quercetin, a widely reported antioxidant found in plants (Zheng et al., 2017). The antioxidant capacity of quercetin has potential to counteract oxidative damage and inflammation in SCD (Cesquini et al., 2003). Quercetin is also reported to inhibit the activity of reactive oxygen species generating enzymes like xanthine oxidase, which could be protective against SCD associated oxidative damage (Zhang et al., 2018). Studies have also shown that quercetin reduced HU induced cytotoxicity in immortalized mouse aortic endothelial cells (Kiser et al., 2017). However, its modulatory role on deoxy-hemoglobin and effects on chemical functional groups of sickle erythrocytes as well as the links with redox homeostasis are still unknown vis-à-vis its sickling-preventive property, thus, necessitating further research along this line. Therefore, this study examined the antisickling effects of quercetin via modulation of deoxyhaemoglobin, redox homeostasis and alteration of functional chemistry in human sickle erythrocytes using in silico and in vitro models while espousing preventive and curative approaches. Findings from this study will go a long way in adding to the knowledge on the potentials of natural products in fighting and dealing with SCD vis-à-vis its metabolic complications.

\subsection{Materials and Method}

\section{Chemicals and Reagents}

Quercetin (302.238g/mol, $\geq 95 \%$ purity) was pure and bought from Sigma Chemical Co. (St. Louis, MO, USA). All additional chemicals/reagents used were of investigative grade until otherwise specified.

\section{In silico Studies}

The structure of a ligand; quercetin (5280343) was repossessed from the major ligand data base, PubChem. A PDB format of the target proteins; deoxygenated haemoglobin (PDB ID: 3WCU) and 2, 3-bisphophoglycerate mutase (PDB ID: 3NFY) were acquired from protein data bank. The proteins groundwork and energy minimization were done with the aid of Discovery studio $2.5 \mathrm{v}$. The CHARMm-based DOCKER program was used to score the interaction between the proteins and the ligand (quercetin) into the crystal structure of the receptors binding compartments (Babangida et al., 2018; Muhammad et al., 2018). The PDB files of the best docked conformation were generated using Accerlrys discovery studio and were introduced into Chimera $1.1 \mathrm{v}$ to generate and view the hydrophobic and hydrophilic interactions. The binding energies and kinetic inhibition constants were similarly calculated (Babangida et al., 2018; Muhammad et al., 2018)

\section{In vitro Studies \\ Collection of Blood Samples}

Five (5) $\mathrm{mL}$ of blood was humanely obtained by venepuncture from each of Seven (7) confirmed sickle cell anaemia patients who were not in crises at Department of Haematology, Ahmadu Bello University Teaching Hospital (ABUTH), Zaria, Kaduna State, Nigeria. They were aged between 19 and 32 years and comprised of both sexes. The patients who were in reasonable stable conditions were duly informed as they provided their consents prior to the recruitment. Blood was collected in an EDTA bottles, cautiously mixed by slight rolling the container. All experiments were carried out under the ethical approval of ABUTH Scientific and Health Research Ethics Committee (ABUTH/HREC/UG/6), in agreement with the 
ethical standards set down in the 1964 Declaration of Helsinki and its later modifications. Regardless, all experiments were conducted with freshly collected blood samples.

\section{Isolation of erythrocytes}

The acquired homozygous HBS samples were spun at $3000 \mathrm{r} / \mathrm{min}$ for 10 min.; the resultant plasma was cast-off to get hold of the erythrocytes. The erythrocytes were suspended in PBS, spun and the supernatant discarded. This was done thrice, after which the washed erythrocytes were ressuspended in PBS and promptly used for assays.

\section{Induction of sickling, antisickling and osmotic fragility Assays}

Exactly $0.1 \mathrm{ml}$ of the extracted erythrocytes were mixed with $0.1 \mathrm{ml}$ of freshly prepared $2 \%$ sodium metabisulphite in a clean and dried test tube and thereafter, incubated in water-bath at $37^{\circ} \mathrm{C}$ for $3 \mathrm{~h}$. A drop of the mixture was then smeared on a microscope slide, fixed with $95 \%$ methanol, dried and stained with 5\% Giemsa (pH 7.2) for 30 min. (Egunyomi et al., $2009)$. It was then examined under a microscope $(\times 100$ magnification). Aliquots were taken at 30 minutes interval for up to $3 \mathrm{~h}$. The counting of cells was carried out by viewing from different fields ( 5 Fields) across the slide. The numbers of both sickle and unsickle cells were counted and the percentages of cells that were unsickle evaluated by the formula:

$(\%)$ Unsickle $=$ Number of unsickle cells $\times 100 /$ Total number of cells

For antisickling assay using quercetin at the final concentrations of 2.5, 5.0, $7.5,10.0$ and $12.5 \mu \mathrm{g} / \mathrm{mL}$, the aforementioned protocol was also used for preventive and curative approaches. For the preventive, cells were treated with the said concentrations before induction using $2 \%$ sodium metabisulphite and vice-versa for the curative approach. Likewise, osmotic fragility test was steered against quercetin after choosing the superlative concentration as hitherto described (Kraus et al., 1997; Muhammad et al., 2016). Briefly, dilution with equal volumes of erythrocyte and phosphate buffer saline $(\mathrm{pH} 7.4)$ was made. This was followed by subsequent addition of $100 \mu \mathrm{L}$ of quercetin to the experimental tubes except control in which phosphate buffer saline was added. Contents of experimental tubes were mildly shaken and thereafter, allowed for $4 \mathrm{~h}$ incubation at $370 \mathrm{C}$. Subsequently, samples were spun at $5000 \mathrm{rpm}$ for 5 minutes and absorbance determined at $540 \mathrm{~nm}$. Furthermore, the same concentration with best antisickling effect was also used for redox and FTIR analyses, correspondingly. However, it is earnest to mention that a single control was employed in this bioassay; i.e. induced sickle erythrocyte with $2 \%$ sodium metabisulphite.

\section{Evaluation of oxidative stress biomarkers}

The most effective concentrations $(5.0 \mu \mathrm{g} / \mathrm{mL}$ for preventive and $7.5 \mu \mathrm{g} / \mathrm{mL}$ for curative studies) with highest antisickling percentage were incubated with $100 \mu \mathrm{L}$ sickle erythrocyte for 3 hours at $370 \mathrm{C}$ as previously described in the above section (Muhammad et al., 2016). Afterward, the cells were spun and the supernatant evaluated for reduced glutathione (GSH) (Ellman, 1959), lipid peroxidation (Chowdhury and Soulsby, 2002), SOD (Kakkar et al., 1984) and catalase activity (Chance and Maehly, 1955).

\section{Fourier transform-infrared spectroscopy analysis}

The best concentrations $(5.0 \mu \mathrm{g} / \mathrm{mL}$ for preventive and $7.5 \mu \mathrm{g} / \mathrm{mL}$ for curative studies) with highest antisickling percentage were incubated with $100 \mu \mathrm{L}$ sickle erythrocyte for 3 hours at $370 \mathrm{C}$ as previously explicated in the above section, while adopting the methods as explained elsewhere (Erukainure et al., 2017). When treated, the samples were dehydrated under pressure and sandwiched between potassium bromide. They were then perused on Fourier transform-infrared spectroscopy (FTIR) spectrophotometer at room temperature $(250 \mathrm{C}-280 \mathrm{C})$ at $1000-3500 \mathrm{~cm}-1$ spectral range. The peak heights were utilised in detecting the functional groups present by relating to the IR spectroscopy correspondence table.

\section{Statistical analysis}

The experiments were conducted at least thrice. The data were presented as mean \pm standard deviation (SD) as the case may be. The data were analyzed using student t-test to compare only the induced and treated group as the case may be, with the aid of Statistical Package for Social Sciences (SPSS) software, SPSS Inc., Chicago, Standard version 20.00. $\mathrm{P}<0.05$ was considered statistically significant for differences in mean.

\subsection{Results}

Deoxygenated haemoglobin and 2, 3-bisphosphoglycerate mutase are central to erythrocytes metabolism so also the SCD. Exploring them as receptors for molecular docking with quercetin as ligand is of great importance. The results show that quercetin had a strong binding affinity for the receptors; deoxygenated haemoglobin and 2, 3-bisphosphoglycerate mutase (Table 1 and 2), suggesting a likely sequestrated and inhibitory effect through molecular interactions (Figure 1 and 2).

Having clues from the predictions based on docking that quercetin may actually modulate deoxygenated haemoglobin and 2, 3bisphosphoglycerate mutase via sequestration, we proceeded with antisickling studies using preventive and curative approaches. To do so, $2 \%$ metabisulphite was first used to induce sickling since the said blood donors were not in crises as at the time of collection. As seen in Table 3, we were able to maximally induce sickling at $3 \mathrm{~h}$ by $73.6 \%$. As such, $3 \mathrm{~h}$ was adopted for our further assays. Interestingly, quercetin administration was able to prevent sickling maximally at $5.0 \mu \mathrm{g} / \mathrm{mL}$ (Table 4 ) and reversed same at $7.5 \mu \mathrm{g} / \mathrm{mL}$ (Table 5), by $83.6 \%$ and $75.9 \%$, respectively (Figure 3 ). Consequently, $5.0 \mu \mathrm{g} / \mathrm{mL}$ and $7.5 \mu \mathrm{g} / \mathrm{mL}$ were selected for further assays since the observed sickling-preventive and curative effects were not dosedependent. By implication, IC50 calculation is not necessary but utilization of the best concentrations.

Stability of erythrocytes membrane is paramount to antisickling effects. As seen in Figure 4, quercetin treatment significantly $(\mathrm{P}<0.05)$ stabilizes the erythrocyte membrane as evident from the observed $\%$ haemolysis relative to control (induced erythrocyte but without treatment) judging from preventive and curative approaches (Figure 4).

From Table 6 treatment with quercetin significantly $(\mathrm{P}<0.05)$ prevented and reversed lipid peroxidation as evident from the amount of MDA generated relative to the induced erythrocyte but without treatment. The same trends were observed for GSH, CAT and SOD except that CAT and SOD activities were not significantly $(\mathrm{P}>0.05)$ differed with untreated, based on preventive approach. However, quercetin considerably $(\mathrm{P}<0.05)$ decreased the level of SOD when administered after induction of sickling (Table 6).

As a result of the observed higher level of lipid peroxidation and negative effects on the part of GSH, CAT and SOD vis-à-vis higher \% haemolysis due to sickling induction, it will be so glaring that the three-dimensional structure of lipid bilayer and proteins could be affected so also their functional chemistry courtesy of oxidative stress. Adjudicating from our FTIR results (Table 7, 8 and 9), one could see a favorable alteration on the part of functional chemistry in terms of shifts (bend and stretches) (Figure 5) and functional groups observed relative to the induced erythrocyte but without treatment (Figure 5) 
Table 1: Molecular docking score $(\mathrm{kcal} / \mathrm{mol})$ and inhibition constant $(\mu \mathrm{M})$ of quercetin at the binding site of deoxygenated haemoglobin
Table 2: Molecular docking score $(\mathrm{kcal} / \mathrm{mol})$ and inhibition constant $(\mu \mathrm{M})$ of quercetin at the binding site of 2, 3bisphosphoglycerate mutase

\begin{tabular}{lllll}
\hline Name & Score & Ki & $\begin{array}{l}\text { Hydrogen } \\
\text { bond }\end{array}$ & $\begin{array}{l}\text { Hydrophobic } \\
\text { interaction }\end{array}$ \\
\hline Quercetin & -30.427 & 0.988 & -7.869 & -2.554 \\
\hline
\end{tabular}

\begin{tabular}{lccll}
\hline Name & Score & Ki & $\begin{array}{l}\text { Hydrogen } \\
\text { bond }\end{array}$ & $\begin{array}{l}\text { Hydrophobic } \\
\text { interaction }\end{array}$ \\
\hline Quercetin & -21.106 & 0.992 & -5.86 & -3.90 \\
\hline
\end{tabular}

Table 3: Percentage sickling after induction with $2 \%$ sodium metabisulphite

\begin{tabular}{|c|c|c|c|c|c|}
\hline Time interval & sickle cells & unsickle cells & Total cells & $\%$ sickle & \%unsickle \\
\hline $30 \mathrm{~min}$. & 46.0 & 96.0 & 142.0 & 32.4 & 67.6 \\
\hline $1 \mathrm{~h}$ & 55.0 & 34.0 & 89.0 & 61.8 & 38.2 \\
\hline $1 \mathrm{~h} 30 \mathrm{~min}$. & 20.0 & 28.0 & 48.0 & 41.7 & 58.3 \\
\hline $2 \mathrm{~h}$ & 227.0 & 160.0 & 387.0 & 58.7 & 41.3 \\
\hline $2 \mathrm{~h} 30 \mathrm{~min}$. & 59.0 & 81.0 & 140.0 & 42.1 & 57.9 \\
\hline $3 \mathrm{~h}$ & 131.0 & 47.0 & 178.0 & 73.6 & 26.4 \\
\hline
\end{tabular}

Table 4: Antisickling effect of quercetin using preventive approach

\begin{tabular}{llllll} 
Concentrations & sickle cells & Unsickle cells & Total cells & \% sickle & \%unsickle \\
\hline $2.5 \mu \mathrm{g} / \mathrm{mL}$ & 192.0 & 355.0 & 547.0 & 35.1 & 64.9 \\
$5.0 \mu \mathrm{g} / \mathrm{mL}$ & 126.0 & 643.0 & 769.0 & 16.4 & 83.6 \\
$7.5 \mu \mathrm{g} / \mathrm{mL}$ & 211.0 & 503.0 & 714.0 & 29.6 & 70.4 \\
$10.0 \mu \mathrm{g} / \mathrm{mL}$ & 136.0 & 245.0 & 381.0 & 35.7 & 64.3 \\
$12.5 \mu \mathrm{g} / \mathrm{mL}$ & 234.0 & 345.0 & 579.0 & 40.4 & 59.6 \\
\hline
\end{tabular}

Table 5: Antisickling effect of quercetin using curative approach

\begin{tabular}{llllll} 
Concentrations & sickle cells & Unsickle cells & Total cells & \% sickle & \%ounsickle \\
\hline $2.5 \mu \mathrm{g} / \mathrm{mL}$ & 189.0 & 464.0 & 653.0 & 28.9 & 71.1 \\
$5.0 \mu \mathrm{g} / \mathrm{mL}$ & 130.0 & 216.0 & 346.0 & 37.6 & 62.4 \\
$7.5 \mu \mathrm{g} / \mathrm{mL}$ & 74.0 & 233.0 & 307.0 & 24.1 & 75.9 \\
$10.0 \mu \mathrm{g} / \mathrm{mL}$ & 81.0 & 246.0 & 327.0 & 24.8 & 75.2 \\
$12.5 \mu \mathrm{g} / \mathrm{mL}$ & 113.0 & 275.0 & 388.0 & 29.1 & 70.9 \\
\hline
\end{tabular}


Table 6: Effect of quercetin on redox sensitive biomarkers on sickle erythrocyte induced with $2 \%$ metabisulphite

\begin{tabular}{lllll}
\hline Treatments & MDA $(\boldsymbol{\mu M})$ & GSH $(\boldsymbol{\mu g} / \mathbf{m L})$ & CAT $(\mathrm{U} / \mathbf{m g}$ protein) & SOD(U/mg protein) \\
\hline Induced with $\mathbf{2 \%}$ metabisulphite & $2.21 \pm 0.02$ & $191.15 \pm 2.31$ & $0.38 \pm 0.03$ & $2.84 \pm 0.56$ \\
Preventive Approach $(\mathbf{5 . 0} \boldsymbol{\mu g} / \mathbf{m L})$ & $1.81 \pm 0.04^{*}$ & $193.87 \pm 1.23^{*}$ & $0.38 \pm 0.02$ & $2.35 \pm 0.07$ \\
Curative Approach $(\mathbf{7 . 5} \boldsymbol{\mu g} / \mathbf{m L})$ & $1.15 \pm 0.03^{*}$ & $231.09 \pm 2.71^{*}$ & $0.84 \pm 0.08^{*}$ & $0.79 \pm 0.07^{*}$
\end{tabular}

*statistically significant $(\mathrm{P}<0.05)$ as individually compared with the induced

Table 7: FTIR results of induced with $2 \%$ metabisulphite/untreated sickle erythrocyte

\begin{tabular}{llll} 
Characteristic absorptions, $\mathbf{c m}^{-\mathbf{1}}$ & Intensity, \%T & Bond & Functional group \\
& & & \\
\hline 3280.1 & 52.9 & $\mathrm{~N}-\mathrm{H}$ stretch & $-\mathrm{CONH} 2 ;-\mathrm{CONH}_{-}$ \\
2959.5 & 74.5 & $\mathrm{C}-\mathrm{H}$ stretch & $\mathrm{C}-\mathrm{H}$ \\
1397.8 & 59.7 & $\mathrm{~N}=\mathrm{O}$ bend & $-\mathrm{R}_{-}-\mathrm{NO}_{2}-$ \\
$1636.3-1539.4$ & $33.6-35.4$ & $\mathrm{~N}-\mathrm{H}$ bend & $-\mathrm{CONH}_{2}$
\end{tabular}

Table 8: FTIR results of treated and induced using preventive approach $(5.0 \mu \mathrm{g} / \mathrm{mL}$ quercetin $)$

\begin{tabular}{llll}
\hline Characteristic absorptions, $\mathbf{c m}^{-\mathbf{1}}$ & Intensity, $\mathbf{\%}$ & Bond & Functional group \\
& & & \\
\hline 3276.3 & 88.8 & $\mathrm{~N}-\mathrm{H}$ stretch & $-\mathrm{CONH} 2 ;-\mathrm{CONH}-$ \\
2877.5 & 92.1 & $\mathrm{C}-\mathrm{H}$ stretch & $\mathrm{C}-\mathrm{H}$ \\
$1543-1640$ & $85.7 ; 80.9$ & $\mathrm{~N}-\mathrm{H}$ bend & $-\mathrm{CONH}_{2}-$ \\
1028.7 & 75.0 & $\mathrm{C}-\mathrm{O}$ stretch & $-\mathrm{C}-\mathrm{O}-\mathrm{C}-$ \\
\hline
\end{tabular}

Table 9: FTIR results of induced and treated using curative approach $(7.5 \mu \mathrm{g} / \mathrm{mL}$ quercetin $)$

\begin{tabular}{llll} 
Characteristic absorptions, $\mathbf{c m}^{-\mathbf{1}}$ & Intensity, $\% \mathbf{T}$ & Bond & Functional group \\
& & & \\
\hline 3276.3 & 94.0 & $\mathrm{~N}-\mathrm{H}$ stretch & $-\mathrm{CONH} 2 ;-\mathrm{CONH}-$ \\
2996.1 & 96.0 & $\mathrm{C}-\mathrm{H}$ stretch & $\mathrm{C}-\mathrm{H}$ \\
1651.2 & 94.1 & $=\mathrm{C}-\mathrm{H}$ stretch & $\mathrm{C}=\mathrm{C}-\mathrm{H}$ \\
1028.7 & 83.01 & $\mathrm{C}-\mathrm{O}$ stretch & $-\mathrm{C}-\mathrm{O}-\mathrm{C}-$
\end{tabular}



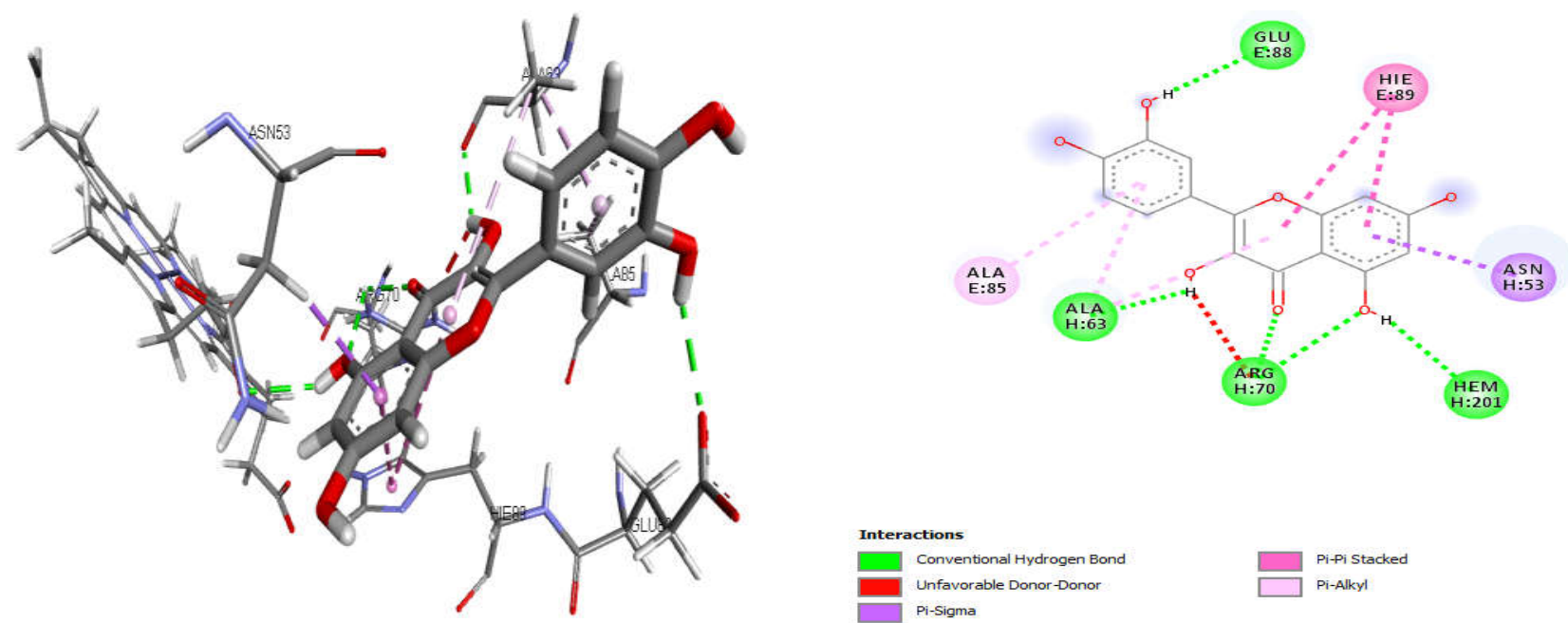

Figure 1: 3D and 2D binding interactions of quercetin with deoxygenated haemoglobin
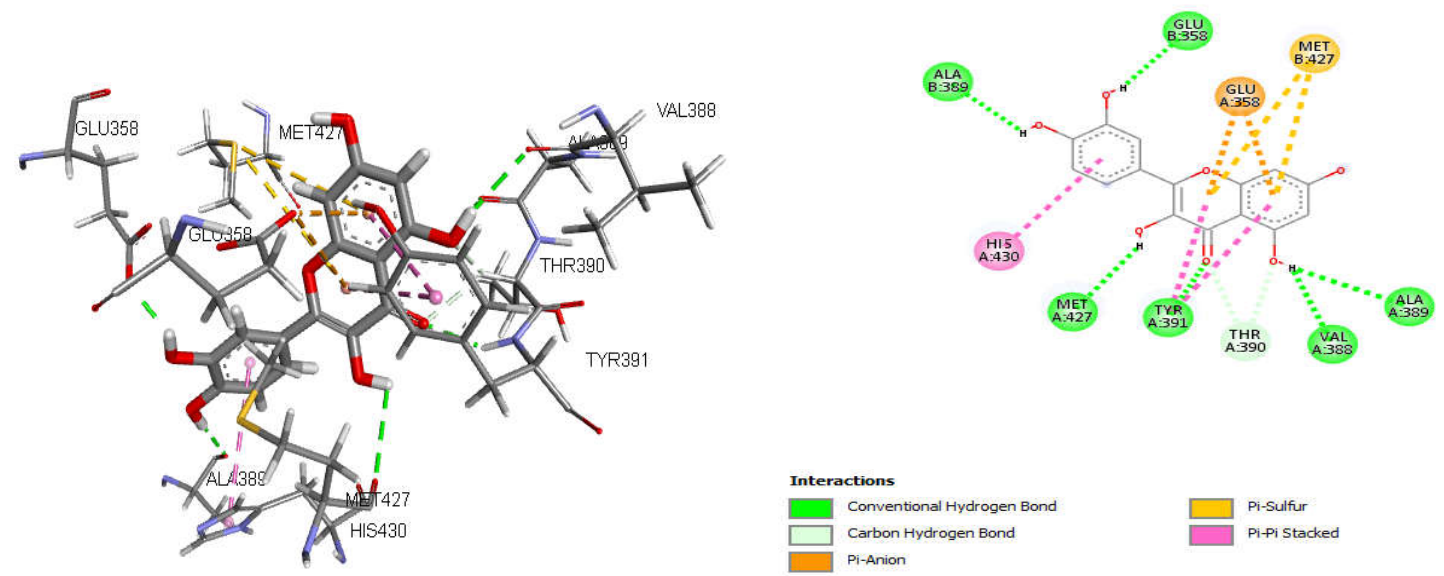

Figure 2: 3D and 2D interaction of quercetin with 2, 3-bisphophoglycerate mutase
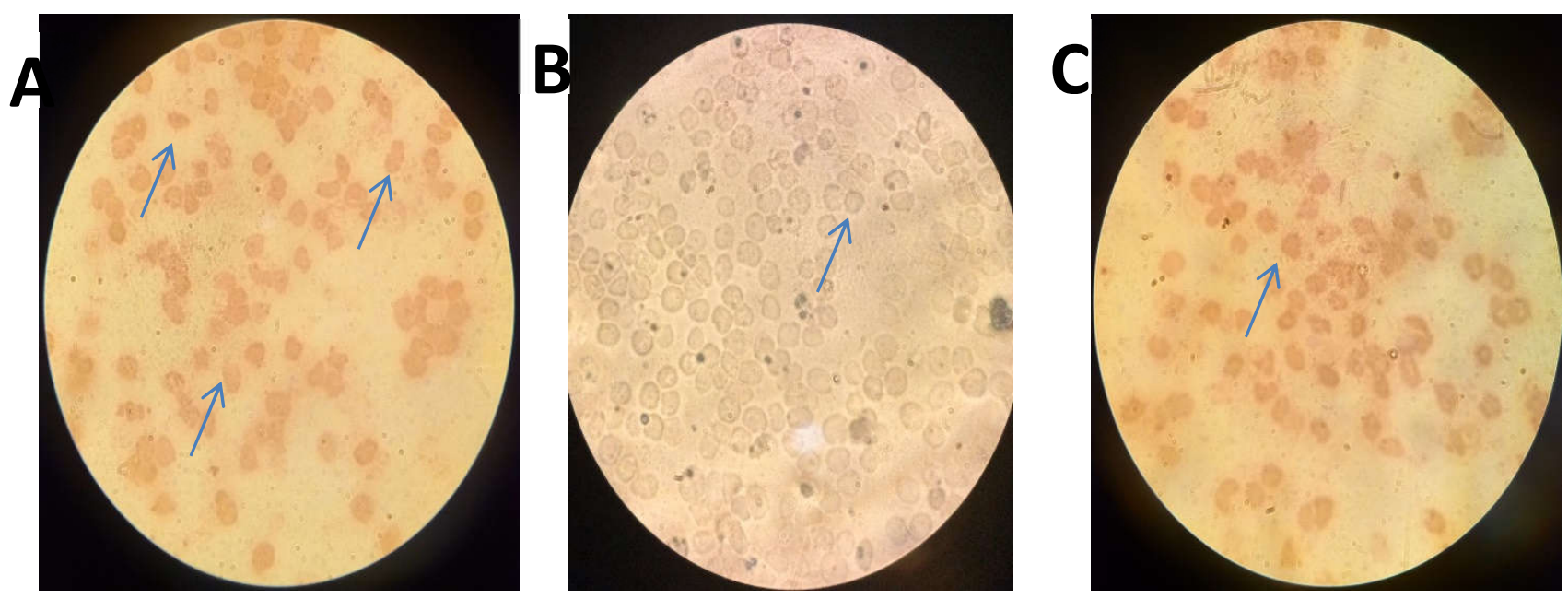

Figure 3: Comparative photomicrograph of induced (A), preventive with $5.0 \mu / \mathrm{mL}$ (B) and curative $7.5 \mu / \mathrm{mL}$ quercetin (C). Stain: Giemsa, magnification $\times 100$. Arrows pointing sickle and normal red blood cells 


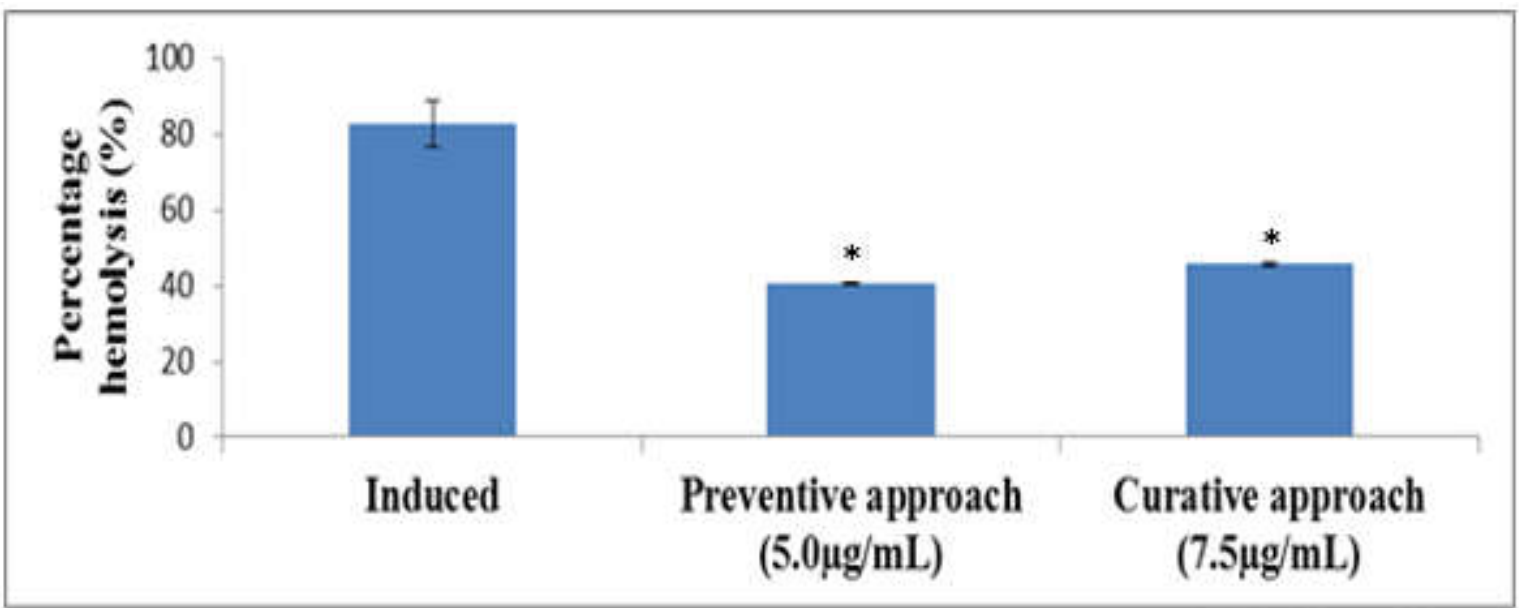

Figure 4: Membrane stabilising effect of quercetin on $2 \%$ metabisulphite-induced sickling in human erythrocyte. *statistically significant $(\mathrm{P}<0.05)$ as individually compared with the induced.

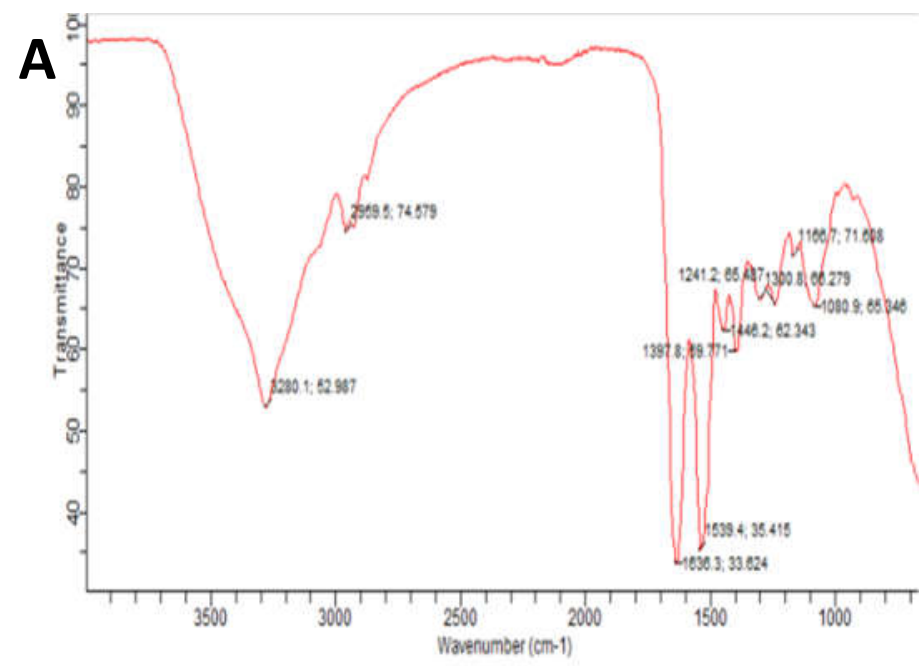

B

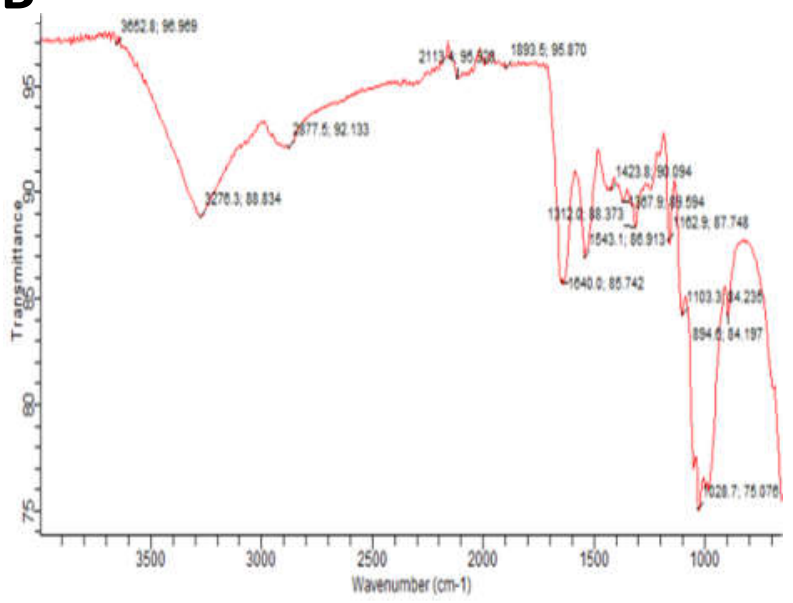

C

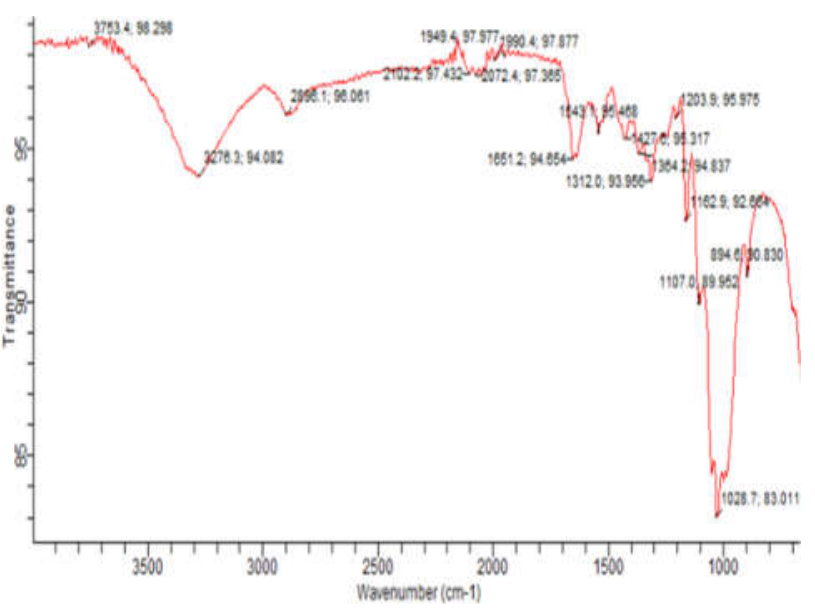

Figure 5: Comparative FTIR peaks between induced (A), preventive with $5.0 \mu \mathrm{g} / \mathrm{mL}(\mathrm{B})$ and curative with $7.5 \mu \mathrm{g} / \mathrm{mL}$ quercetin $(\mathrm{C})$ 


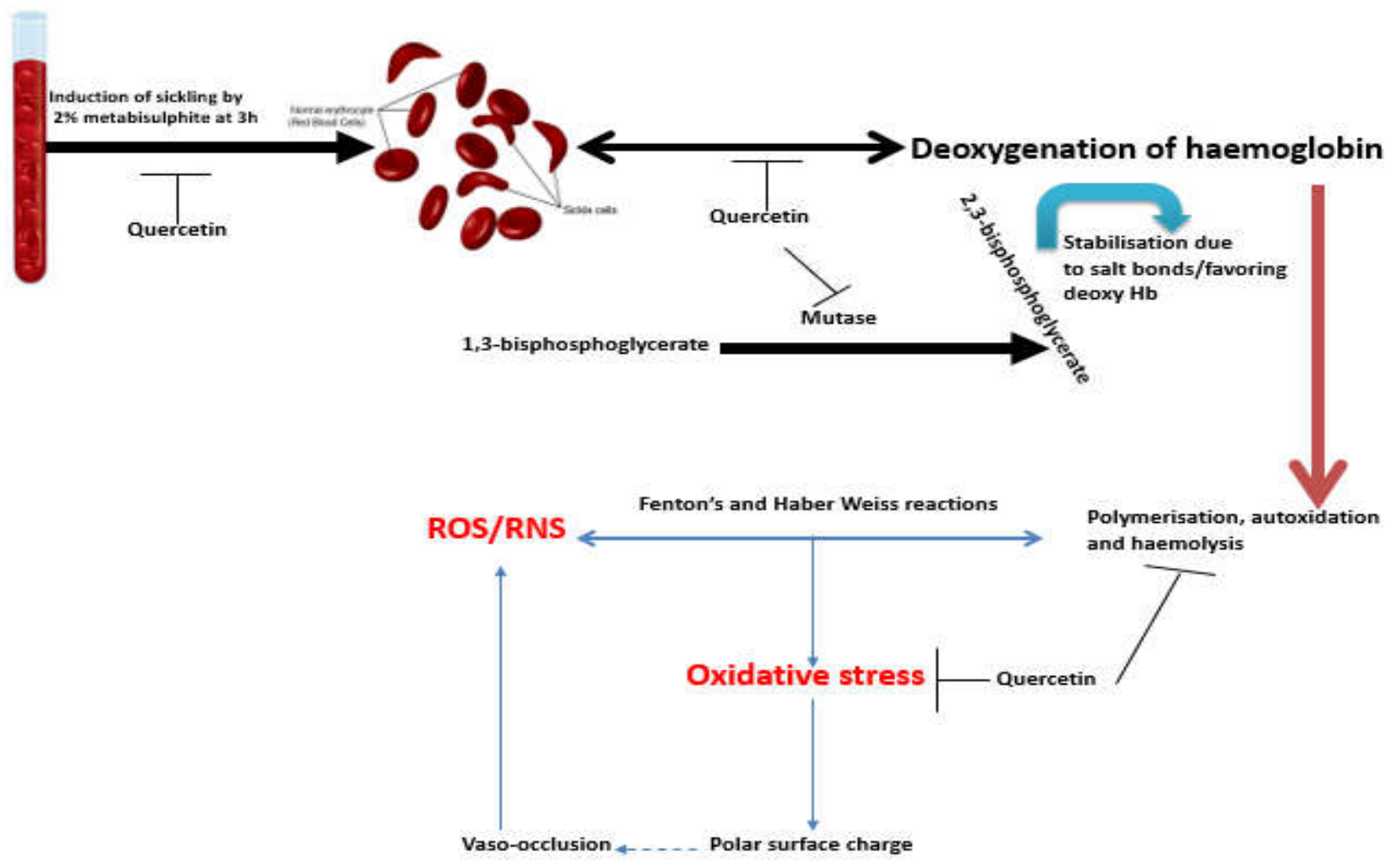

Figure 6: Proposed antisickling mechanism of quercetin

\subsection{DISCUSSION}

As a result of the facts that orthodox drugs established so far for sickle cell management concentrate mainly on indicative respite of pain and crisis mitigation, scientists have so far continually had a rethink of paradigm move from artificial drugs to medicinal plants. These medicinal plants are naturally endowed with bioactive compounds with strong biological activities including antisickling (Ngozi, 2013). One of such bioactive compounds is a quercetin that can be easily sourced from our microenvironment via consumption of grains, fruits and vegetables. Equally, side effects associated with orthodox drugs ingestion, availability and affordability, particularly in developing countries are some the reported issues of major concern (Erukainure et al., 2017).

Sickle cell disease (SCD) remains a major inherited hemoglobinopathy amongst Africans, with sub-Saharan Africa among the most affected (Erukainure et al., 2017). It is an inherently inbred ailment in which the "SS" individual possesses a nonconforming beta globin gene. The single base switch in the gene encoding the human $\beta$-globin subunit leads to replacement of $\beta 6$ glutamic acid by valine, and therefore bringing in an overwhelming medical manifestation of SCD (Ngozi, 2013). This exchange causes a radical lessening in the solubility of sickle cell hemoglobin $(\mathrm{HbS})$ once deoxygenated, exacerbated by higher level of 2, 3-

This journal is (C) The Nigerian Young Academy 2019 bisphosphoglycerate due to increase in activity of 2, 3-bisphosphoglycerate mutase (Poillon et al., 1995). In these precarious conditions, the hemoglobin molecules polymerize into crystalline intracellular mass of fibers which are blamable for the distortion of the biconcave disc shaped erythrocyte into a sickle shape (Ngozi, 2013). Subsequently, this activates the release of haemoglobin and iron into plasma. The HbS undergoes a spontaneous autoxidation thereby persuading the formation of methemoglobin and superoxide radical (Silva et al., 2013). The superoxide radical dismutase's to hydrogen peroxide, which amasses and reacts with methemoglobin to produce hydroxyl radical via Fenton's and Haber Weiss reactions. These are of course the hallmarks of oxidative damage as part of the secondary metabolic complications associated with SCD (Damanhouri et al., 2015). Therefore, this study was aimed at examining the antisickling effects of quercetin via modulation of deoxy-haemoglobin, redox homeostasis and alteration of functional chemistry in human sickle erythrocytes using in silico and in vitro models while championing preventive and curative approaches.

In silico studies carried out with quercetin on deoxy-haemoglobin and 2, 3bisphophoglycerate mutase, showed a strong interaction, which was found to effectually bind with the receptors by fully inhabiting their catalytic sites. Higher levels of deoxy-haemoglobin and 2,3-bisphophoglycerate mutase have been reported in SCD (Ngozi, 2013; Poillon et al., 1995; Rowley et al., 2014). Consequently, targeting these proteins via sequestration as

Annals of Science and Technology 2019 Vol. 4 (1) 38-47 |45 
clearly revealed in our study may provide a viable tactic in challenging and managing sickle cell anaemia in addition to offering a clue on the antisickling potentials of quercetin. This can be logically supported from the evidences obtained from our previous study that flavonoids certainly had a strong attraction to proteins based on hydrophobic and hydrophilic interactions (Babangida et al., 2018). By inference, this might have revealed a quercetin's inclination to allosterically bind to haemoglobin with strong affinity that may potentially adjust oxygen's affinity to haemoglobin in favor of oxygenation supported by the observed potential inhibitory effects on 2, 3-bisphophoglycerate mutase.

Corroborating our docking results, pre and post-treatment with quercetin decreased the number of sickle erythrocytes suggesting a protective and curative role of quercetin against sickling of erythrocytes. This is possible because, the sickling process in SCD patients is characterized by continuous polymerization of erythrocytes due to oxidative stress in addition to inadequate oxygen supply typical of sickle erythrocytes (Erukainure et al., 2017; Ngozi, 2013; Poillon et al., 1995). The antioxidant properties of quercetin can protect against oxidative stress that further contribute to the stability of sickle erythrocyte membranes (Zheng et al., 2017). This agrees with earlier studies which showed that treatment with quercetin counteracted oxidative stress levels in treated experiments when compared to non-quercetin treated controls (Gibellini et al., 2011). The pragmatic changes of the functional chemistry may potentially be connected with a membrane stabilizing effect of Quercetin in an untreated as opposed to treated erythrocytes judging from the facts that erythrocytes compared to other cells composed of lipids, proteins and carbohydrates extracellularly, integral or/and intracellularly. Quercetin has also been reported to have a high bioavailability which enhances its antioxidant effects as evidenced by the observed reduction in lipid peroxidation with simultaneous increased in GSH, CAT and SOD in the current study (Egert et al., 2008; Kiser et al., 2017). Its administration has been shown to have anti-inflammatory and protein stability effects which could be advantageous in combating SCD associated oxidative stress, inflammation and decreased HbS stability (Askari et al., 2012). These may as well alleviate and possibly reverse throbbing vaso-occlusive events branded by endothelial dysfunction and instigation of the inflammatory as well as coagulation pathway lately described in SCD (Erukainure et al., 2017; Macharia et al., 2018; Sani et al., 2015).

\subsection{CONCLUSION}

From our results it can thus be reasoned that, antisickling potentials of quercetin may be associated with modulation of deoxy-haemoglobin, redox homeostasis and alteration of functional chemistry in human sickle erythrocytes in vitro. Additional studies are desirable to examine the antisickling potency of quercetin in other SCD study models and also to asses if co-treatment of quercetin with $\mathrm{HU}$ will protect against oxidative stress and cytotoxicity experienced by patients on HU therapy vis-à-vis quantifying the levels of deoxy-haemoglobin and 2, 3-bisphosphoglycerate mutase.

\section{Conflict of Interest}

The authors declare no conflict of interest.

\section{Acknowledgement}

We are thankful to the guidance and support of Mrs. Zeenat Bello Kudan and Miss Funmi Audu E. from the Department of Biochemistry, Ahmadu Bello University, Zaria, towards the effective conclusion of this work. We similarly appreciate Mrs. Salamatu Sani of the Department of English and literary studies, Ahmadu Bello University, Zaria for improving manuscript's quality.

\section{Authors Contribution}

Conception: $\mathrm{AM}$ and $\mathrm{BM}$

Design: AM, IM, IBA, HAM and GEF

Execution: MFA, ATN and BS

Interpretation: AM, IM, IBA, HAM and GEF

Writing the paper: AM, HS, GEF and BS

Proofreading the paper: HS and HAM

\section{References}

Adewoyin, A.S., 2015. Management of sickle cell disease: a review for physician education in Nigeria (sub-saharan Africa). Anemia 2015, 791498. https://doi.org/10.1155/2015/791498

Adewoyin, A.S., Alagbe, A.E., Adedokun, B.O., Idubor, N.T., 2015. Knowledge, attitude and control practices of sickle cell disease among youth corps members in Benin city, Nigeria. Ann. Ibadan Postgrad. Med. 13, 100-7.

Adewoyin, A.S., Oghuvwu, O.S., Awodu, O.A., 2017. Hydroxyurea therapy in adult Nigerian sickle cell disease: a monocentric survey on pattern of use, clinical effects and patient's compliance. Afr. Health Sci. 17, 255-261. https://doi.org/10.4314/ahs.v17i1.31

Askari, G., Ghiasvand, R., Feizi, A., Ghanadian, S.M., Karimian, J., 2012. The effect of quercetin supplementation on selected markers of inflammation and oxidative stress. J. Res. Med. Sci. 17, 637-41. https://doi.org/10.1016/j.anbehav.2003.08.027

Babangida, S., Ibrahim, S., Muhammad, A., Arthur, D.E., Uzairu, A., Garba, A., 2018. The role of molecular modelling strategies in validating the effects of chrysin on sodium arsenite-induced chromosomal and DNA damage. Hum. Exp. Toxicol. 1-11. https://doi.org/10.1177/0960327117751233

Brandow, A.M., Panepinto, J.A., 2010. Hydroxyurea use in sickle cell disease: the battle with low prescription rates, poor patient compliance and fears of toxicities. Expert Rev. Hematol. 3, 255-60. https://doi.org/10.1586/ehm.10.22

Cesquini, M., Torsoni, M.A., Stoppa, G.R., Ogo, S.H., 2003. t-BOOHinduced oxidative damage in sickle red blood cells and the role of flavonoids. Biomed. Pharmacother. 57, 124-9.

Chance, B., Maehly, A.C., 1955. Assays of catalases and peroxidases. Meth Enzym.

https://doi.org/http://dx.doi.org.ez66.periodicos.capes.gov.br/10.1016 /S0076-6879(55)02300-8

Chowdhury, P., Soulsby, M., 2002. Lipid peroxidation in rat brain is increased by simulated weightlessness and decreased by a soy-protein diet. Ann. Clin. Lab. Sci. https://doi.org/10.1016/j.pt.2006.02.009

Damanhouri GA, Jarullah J, M.S., 2015. Clinical biomarkers in sickle cell disease. Saudi J. Biol. Sci. 22, 24-31. 
Egert, S., Wolffram, S., Bosy-Westphal, A., Boesch-Saadatmandi, C., Wagner, A.E., Frank, J., Rimbach, G., Mueller, M.J., 2008. Daily quercetin supplementation dose-dependently increases plasma quercetin concentrations in healthy humans. J. Nutr. 138, 1615-1621. https://doi.org/138/9/1615 [pii]

Egunyomi, A., Moody, J.O., Eletu, O.M., 2009. Antisickling activities of two ethnomedicinal plant recipes used for the management of sickle cell anaemia in Ibadan, Nigeria. African J. Biotechnol. 8, 20-25.

Ellman, G.L., 1959. Tissue sulfhydryl groups. Arch. Biochem. Biophys. https://doi.org/10.1016/0003-9861(59)90090-6

Erukainure, O., Ajiboye, J., Abbah, U., Asieba, G., Mamuru, S., Zaruwa, M.Z., Manhas, N., Singh, P., Islam, M.S., 2017. Monodora myristica ( African nutmeg ) modulates redox homeostasis and alters functional chemistry in sickled erythrocytes. Hum. Exp. Toxicol. 37, 458-467. https://doi.org/10.1177/0960327117712385

Gibellini, L., Pinti, M., Nasi, M., Montagna, J.P., Biasi, S. De, Roat, E., Bertoncelli, L., Cooper, E.L., Cossarizza, A., 2011. Quercetin and Cancer Chemoprevention. Evidence-based Complement. Altern. Med. 2011, 15. https://doi.org/10.1093/ecam/neq053

Kakkar, P., Das, B., Viswanathan, P.N., 1984. A modified spectrophotometric assay of superoxide dismutase. Indian J. Biochem. Biophys. https://doi.org/10.1097/YCO.0b013e3280117733

Kiser, Z.M., McGee, M.D.M., Wright, R.J., Quarshie, A., Newman, G.W., Randall, K.R., Stiles, J.K., Driss, A., Hibbert, J.M., 2017. Quercetin reduces hydroxyurea induced cytotoxicity in immortalized mouse aortic endothelial cells. PeerJ 31, e3376. https://doi.org/10.7717/peerj.3376

Kraus, A., Roth, H.P., Kirchgessner, M., 1997. Influence of vitamin C, vitamin $\mathrm{E}$ and beta-carotene on the osmotic fragility and the primary antioxidant system of erythrocytes in zinc-deficient rats. Arch. Tierernahr. 50, 257-269.

Macharia, A.W., Mochamah, G., Uyoga, S., Ndila, C.M., Nyutu, G., Makale, J., Tendwa, M., Nyatichi, E., Ojal, J., Shebe, M., Awuondo, K.O., Mturi, N., Peshu, N., Tsofa, B., Scott, J.A.G., Maitland, K., Williams, T.N., 2018. The clinical epidemiology of sickle cell anemia In Africa. Am. J. Hematol. 93, 363-370. https://doi.org/10.1002/ajh.24986

Mohanty, J.G., Nagababu, E., Rifkind, J.M., 2014. Red blood cell oxidative stress impairs oxygen delivery and induces red blood cell aging. Front. Physiol. 5, 84. https://doi.org/10.3389/fphys.2014.00084

Muhammad, A., Arthur, D.E., Babangida, S., Erukainure, O.L., Malami, I., Sani, H., Abdulhamid, A.W., Ajiboye, I.O., Saka, A.A., Hamza, N.M., Asema, S., Ado, Z.M., Musa, T.I., 2018. Modulatory role of rutin on 2,5-hexanedione-induced chromosomal and DNA damage in rats: validation of computational predictions. Drug Chem. Toxicol. 10, 114. https://doi.org/doi: 10.1080/01480545.2018.1465948

Muhammad, A., Ibrahim, M.A., Erukainure, O.L., Habila, N., Idowu, A.A., Ndidi, U.S., Malami, I., Zailani, H., Kudan, Z.B., Muhammad, B.A., 2016. Induction of Haemolysis and DNA Fragmentation in a Normal and Malarial-Infected Blood by Commonly - used Antimalarial Drugs in the North-Western Region of Nigeria. Drug Metab. Lett. 10, 49-55.

Nevitt, S.J., Jones, A.P., Howard, J., 2017. Hydroxyurea (hydroxycarbamide) for sickle cell disease. Cochrane Database Syst. Rev. 4, CD002202. https://doi.org/10.1002/14651858.CD002202.pub2
Ngozi Awa Imaga, 2013. Phytomedicines and nutraceuticals: Alternative therapeutics for sickle cell anemia. Sci. World J. 2013, 12. https://doi.org/http://dx.doi.org/10.1155/2013/269659

Okorie, C.P., Nwagha, T., Ejezie, F., 2018. Assessment of some indicators of oxidative stress in nigerian sickle cell anemic patients. Ann. Afr. Med. 17, 11-16. https://doi.org/10.4103/aam.aam_26_17

Oslund, R.C., Su, X., Haugbro, M., Kee, J.-M., Esposito, M., David, Y., Wang, B., Ge, E., Perlman, D.H., Kang, Y., Muir, T.W., Rabinowitz, J.D., 2017. Bisphosphoglycerate mutase controls serine pathway flux via 3-phosphoglycerate. Nat. Chem. Biol. 13, 1081-1087. https://doi.org/10.1038/nchembio.2453

Poillon, W.N., Kim, B.C., Labotka, R.J., Hicks, C.U., Kark, J. a, 1995. Antisickling effects of 2,3-diphosphoglycerate depletion. Blood 85, 3289-3296.

Rees, D.C., 2011. The rationale for using hydroxycarbamide in the treatment of sickle cell disease. Haematologica 96, 488-491. https://doi.org/10.3324/haematol.2011.041988

Rifkind, J.M., Nagababu, E., Ramasamy, S., Ravi, L.B., 2004. Hemoglobin redox reactions and oxidative stress. Redox Rep. 8, 234-237. https://doi.org/10.1179/135100003225002817

Rowley, C.A., Ikeda, A.K., Seidel, M., Anaebere, T.C., Antalek, M.D., Seamon, C., Conrey, A.K., Mendelsohn, L., Nichols, J., Gorbach, A.M., Kato, G.J., Ackerman, H., 2014. Microvascular oxygen consumption during sickle cell pain crisis. Blood 123, 3101-4. https://doi.org/10.1182/blood-2013-11-533406

Sani, H.L., Malami, I., Hassan, S.W., Alhassan, A.M., Halilu, M.E., Muhammad, A., 2015. Effects of standardized stem bark extract of Mangifera indica $\mathrm{L}$. In wistar rats with 2,4-dinitrophenylhydrazineinduced haemolytic anaemia. Pharmacogn. J. 7. https://doi.org/10.5530/pj.2015.2.2

Sedrak, A., Kondamudi, N.P., 2018. Sickle Cell Disease, StatPearls. StatPearls Publishing.

Silva DGH, Belini Junior E, de Almeida EA, B.-D.C., 2013. Oxidative stress in sickle cell disease: An overview of erythrocyte redox metabolism and current antioxidant therapeutic strategies. Free Radic. Biol. Med. 65, 1101-1109. https://doi.org/doi: 10.1016/j.freeradbiomed.2013.08.181

Teixeira, R.S., Terse-Ramos, R., Ferreira, T.A., Machado, V.R., Perdiz, M.I., Lyra, I.M., Nascimento, V.L., Boa-Sorte, N., Andrade, B.B., Ladeia, A.M., 2017. Associations between endothelial dysfunction and clinical and laboratory parameters in children and adolescents with sickle cell anemia. PLoS One 12, e0184076. https://doi.org/10.1371/journal.pone.0184076

Zhang, C., Wang, R., Zhang, G., Gong, D., 2018. Mechanistic insights into the inhibition of quercetin on xanthine oxidase. Int. J. Biol. Macromol. 112, 405-412. https://doi.org/10.1016/j.ijbiomac.2018.01.190

Zheng, Y.-Z., Deng, G., Liang, Q., Chen, D.-F., Guo, R., Lai, R.-C., 2017. Antioxidant Activity of Quercetin and Its Glucosides from Propolis: A Theoretical Study. Sci. Rep. 7, 7543. https://doi.org/10.1038/s41598017-08024-8 